\title{
APPLICATION OF THE PRINCIPLES OF CORPORATE GOVERNANCE IN AGRICULTURE COOPERATIVES
}

\author{
Goran Maričić1, Sanja Škorić², Danijela Radenković ${ }^{3}$ \\ *Corresponding author E-mail: sanja@pravni-fakultet.info
}

\begin{abstract}
A R T I C LE IN F O
A B S T R A C T

Review Article

Received: 02 April 2018

The principles of corporate governance in the global

Accepted: 07 June 2018 economies and in the process of globalization are recognized and stated as extremely important, first in the successful business of companies and gaining doi:10.5937/ekoPolj1802827M

UDC $347.72 .037: 338.43$ competitiveness on the market, and then in the successful resolution of possible conflicts and conflicts of different interest groups within the companies themselves.

Keywords:

corporate governance, agriculture cooperatives, strategic development

JEL: K20, L50, Q13

However, can corporate governance principles be applied in agricultural cooperatives, which now, more than ever, require a good organization, the structure of the rules on which they will be more organized on the market and represent the interests of their cooperatives? By analyzing the cooperative sector, it's been attempted to integrate the principles of corporate governance, with the functioning of agricultural cooperatives, their basic values, organization, traditional organization, etc. in a way that they do not stand one against the other, but one in the function of the other, as a mutual complement.
\end{abstract}

(C) 2018 EA. All rights reserved.

\section{Introduction}

The transition period in Serbia and in the surrounding countries takes almost thirty years, as much as the fundamental changes in the socio-economic environment and the transition from one mode of economics system, socialist, to other - capitalist. Corporate governance in these economies has a crucial character, that is, in the case of recapital transition ie in the case of the recapital transition (Josifidis, 2004).

During the transition period in the Republic of Serbia there was no significant change in the economic structure. Since the beginning of the 21 st century, the

1 Goran Maricic, PhD, Office for Joint Affairs of the Government of the Republic of Srpska, Director of the Service, Republic of Srpska Square no.1, Banja Luka, Republic of Srpska, BiH, Phone: +387 51338 323, E-mail: g.maricic@szp.vladars.net

2 Sanja Skoric, Ph.D, Assistant Professor, Law faculty for commercial and judicary in Novi Sad, Geri Karolja Street no.1, Novi Sad, Phone: +381 21400 499, E-mail: sanja@pravni-fakultet.info

3 Danijela Radenkovic, Ph.D, Assistant Professor, Belgrade Business School - College of Professional Studies in Belgrade, Kraljice Marije Street no. 73, Beograd, Phone: +381 11 3042 300, E - mail: danijela.radenkovic@pr.ac.rs

http://ea.bg.ac.rs 
contribution of agriculture to gross domestic product has declined, primarily as a result of faster growth in activities in non-productive sectors (primarily trade). However, the share of agriculture in the structure of gross value added (GVA) of the economy of the Republic of Serbia is still very high. Compared to the average of the EU countries (27 Member States), the Republic of Serbia has a significantly higher share of GVA of the agriculture sector in total GVA, and significantly lower participation of the service sector. The high share of agriculture in the basic macroeconomic aggregates of the Republic of Serbia in relation to other countries can, on the one hand, be attributed to rich natural resources and favorable climatic conditions for agricultural production, and on the other hand slower to the process of structural reforming of the rest of the economy and delays in that process.

Table 1. Macroeconomic indicators of the contribution of agriculture to the national economy

\begin{tabular}{|l|c|c|c|c|}
\hline & $\mathbf{2 0 1 0}$ & $\mathbf{2 0 1 1}$ & $\mathbf{2 0 1 2}$ & $\mathbf{2 0 1 3}$ \\
\hline $\begin{array}{l}\text { GVA of agriculture, forestry, hunting and fishing (in } \\
\text { millions of RSD) }\end{array}$ & 245.128 & 292.191 & 279.126 & 344.32 \\
\hline Share of GVA of agriculture in total GVA (\%) & 9.9 & 10.5 & 9.7 & 11.4 \\
\hline Employment in agriculture, forestry, hunting and fishing & 533 & 478.1 & 467.1 & 492 \\
\hline Share of agriculture in total employment (\%) & 22.2 & 21.2 & 21 & 21.3 \\
\hline Export of agricultural food products (in millions of euros) & 1700 & 1956 & 2131 & 2104 \\
\hline Participation of agriculture in total exports of goods (\%) & 23 & 23.2 & 24.1 & 23.4 \\
\hline
\end{tabular}

Source: The Strategy of Agriculture and Rural Development of the Republic of Serbia for the period of 2014-2014.

If this result of the share of agriculture in the gross domestic product is linked to the gross added value of this sector with the state obligation to create an institutional framework for better functioning of agriculture, how is it possible that the cooperative sector in Serbia is left out of the focus of these new institutional and economic reforms? If the previous one is added the fact that the agricultural activity is still carried out through crushed agricultural holdings, which without association can not achieve adequate competitiveness on the market, then the state's need to stimulate the development of cooperatives in agriculture is a clear and absolutely necessary. In the National Agriculture and Rural Development Strategy of the Republic of Serbia for the period 2014-2024 ("Official Gazette of RS" No. 85/14), problems and challenges that are followed by agricultural legislation in Serbia have been identified. Namely, it has been established that transition political solutions have not sufficiently taken into account the specificities of the cooperative sector and that in that sense a radical reform of the agricultural legislation is necessary. The main problem is:

Agricultural cooperatives in the Republic of Serbia, besides using their own capacities, organize production on agricultural holdings of about 31 thousand cooperatives and cooperate with about 100 thousand cooperators. It is estimated that agricultural holdings, which are covered by some kind of cooperation with the cooperative, have about half 
of the cattle stock and agricultural land. The nature of the business relationship of cooperatives and agricultural producers is such that agricultural cooperatives finance initial investments for cooperatives and subcontractors, which practically take up the double risk: as suppliers of raw materials on the one hand, and as creditors in settling obligations towards suppliers, on the other.

The period from 2000 to 2013 is characterized by an accelerated process of privatization of social capital and the implementation of a series of systemic reforms, mostly bypassing agricultural cooperatives. Farming cooperatives were exempted from the privatization process, which was supposed to give them additional incentives for strengthening and development.

However, the unresolved problem of property-legal relations, an inequitable approach the capital market and the devastating effects of the gray economy have affected the slowdown the reform of the cooperative movement. Under the influence of these movements, the identity of cooperative property and trust in the cooperative system was lost. Until today no uniform mechanisms for monitoring the situation in the cooperative sector have been established and no ministry has precise and reliable data on the situation in this sector. Cooperative sector support programs that have been provided by individual ministries over the past years have been ad hoc, incompatible with each other and systematically unregulated. Some of the key problems that paralyze the more efficient transformation of the cooperative sector are:

1) unresolved property-legal relations and the issue of cooperative property as a collective type of private property;

2) that the agricultural cooperatives in the Republic of Serbia do not have their own processing facilities, which would be particularly useful in the processing of milk and meat, fruits and vegetables, industrial plants, confectionery industry and others. Therefore cooperatives are excluded from the market of final food products and do not appear in that part of the food chain. In addition, a good part of the storage capacities in the meantime is technically and technologically obsolete due to lack of investments in the maintenance and innovation of equipment;

3) that farmers' cooperatives have been faced with a difficult access to the capital market for (too)long, and in this respect they are in a more unfavorable position than small and medium-sized legal entities and long-standing participants;

4) that co-operatives for a longer period were not users of current and development incentives of MAFWE for their own production. In 2011, agricultural cooperatives for the first time since 2004 could use milk premiums and premiums for genetic improvement in livestock production for their own production, under the same conditions as agricultural holdings of natural persons and economic entities with majority state capital. Only from 2013, agricultural cooperatives robble to use direct incentives for registered co-ownership; 
5) that the existing systematic solutions of other ministries do not recognize the specifics of agricultural cooperatives and do not provide specific solutions to help their revitalization;

6) that cross-sectoral cooperation is underdeveloped and reduced to a large extent in cooperatives in a narrower local environment. Loaded by the existential problems cooperatives completely ignored the segment of interdepartmental cooperation, as well as the concern for human resources and their strengthening. The number of existing production associations of all kinds is extremely high, especially in primary agricultural production. Producer associations are poorly developed, and their role and activities are small. Most of the producer associations are at a low level of organization, which, first of all, marks a low level of professionalism and a lack of management personnel. In recent years, associations have become more and more visible, in particular, in the situations where a market has emerged, but their bargaining power is generally low due to high dependence on the processing industry.

So, the Strategy as one of the problems, states a low degree of professionalism and a lack of management personnel, low negotiating power, and so on. After the adoption of the aforementioned Strategy, a new Law on Cooperatives was adopted in the Republic of Serbia, which was supposed to solve the observed robbery at the institutional level.

On the basis of this, it is very easy to notice the need to apply the basic principles of corporate governance in agricultural cooperatives, which could further improve agricultural cooperatives.

\section{Materials and methods}

Agricultural cooperatives, as a form of association, have a long history and specific values that determine their significance, both through history, and in contemporary conditions, where their values are recognized, both in raising the competitiveness of domestic production and improving the negotiating position of agricultural producers of associated in cooperatives (Vukoje \& Zekić, 2010), and so in determining the prices of agricultural products on the market (Vignjević - Đorđević et al, 2015). Precisely in the conditions of market economy instability and frequent crises, corporate governance principles should contribute to reducing the risk to equity holders, which can at the same time mean reducing the risk to cooperatives through multiple decision-making controls. This should be added to the mentioned share of agricultural production in the total gross of domestic product, in order to gain a true picture of the importance of a well organized system of agricultural cooperatives in our country.

In the theoretical part of the paper, the method of theoretical analysis of contents was primarily applied with the sociological, historical and comparative method, normatively dogmatic method, than basic methods of concretization and specialization, while statistical and analytical-deductive methods were used in the research part of the paper.

The research is based on official statistical data of Statistical Office of the Republic of Serbia, data of Agency for Business Registers and data of Chamber of Commerce of the Republic of Serbia. 


\section{Results}

Since the mid-19th century, the first forms of cooperative organization have been created in Europe, primarily craftsmen, and then farmers.

The first cooperative in the world was founded in Rochdale, England, in 1844 (Rochdale weavers) and it was a modern consumer co-operative, whose foundation marked the beginning of a new era of contemporary association (Tomić et al., 2017).

In the theory of the cooperative movement, several types of cooperative organization can be distinguished, however, three basic directions have also influenced the cooperative organization in our area:

1. The Rochdale model - formed in England after the strike of 1833, which implied free entry and exit from the cooperative, the equality of all cooperatives regardless of the number of subscribed shares - the "one man - one vote" principle, the division of profit according to the scope of purchase, the payment in cash, political neutrality, limited interest in the share capital/

2. The Raiffeisen model, formed in Germany in 1848 at a time of great winter hunger - in order to provide the poor layers of the population with basic foods. As early as 1854, the first credit union was founded - the self-help of the cooperatives in a limited territory, entering into a cooperative without a share, solidarity and unlimited liability, bringing the surplus profits into an indivisible cooperative reserve fund, operating exclusively with cooperatives and free exercise of office.

3. The Schulze-Delic's model of cooperative organization, which was also formed in Germany in 1849, when a deputy of the Prussian Parliament founded a sick and mortar treasury, shoe and table joint-stock cooperatives, and in 1850 a credit union. This way of organization involved a large number of cooperatives, the complete exclusion of state aid, the creation of a reserve fund that can be shared, the attraction of capital through rewards, solidarity and limited liability and business specialization (http://www.zssrbije.org/istorijazadrugarstva.html).

The first co-operative (agricultural credit union) in the territory of today's Serbia was founded in today's Backi Petrovac, in 1846 and it was also the third cooperative founded in the world (Tomić et al., 2017).

The first cooperatives established certain principles of cooperative society, which later became permanent principles of the work of consumer cooperatives in general, such as: the principle of self-help, the principle of democracy, the principle of neutrality, the principle of profit distribution, the principle of selling for cash, the principle of selling at liquid drinks prices, 
Table 2. Important years in the Serbian co-operative society

\begin{tabular}{|c|c|}
\hline Year & Happening \\
\hline $\mathbf{1 8 9 5}$ & The Main Association of Serbian Agricultural Cooperatives was established in Smederevo \\
\hline $\mathbf{1 8 9 7}$ & The Association of Serbian Agricultural Cooperatives based in Zagreb was founded \\
\hline $\mathbf{1 9 8 9}$ & Decree on promulgation of the Law on Agricultural and Craft Cooperatives \\
\hline $\mathbf{1 9 0 0}$ & There were more than 650 cooperatives in Serbia \\
\hline $\mathbf{1 9 2 3}$ & The main alliance merged with the Alliance in Zagreb, after which a total of 1962 a.c. \\
\hline $\mathbf{1 9 3 7}$ & The Law on Economic Co-operatives has been adopted \\
\hline $\mathbf{1 9 4 6}$ & $\begin{array}{c}\text { The Constitution emphasized the role and significance of the general and peasants' early } \\
\text { cooperatives }\end{array}$ \\
\hline $\mathbf{1 9 4 9}$ & The Basic Law on Agricultural Cooperatives has been adopted \\
\hline $\mathbf{1 9 5 3}$ & Reorganization of peasant work cooperatives \\
\hline $\mathbf{1 9 5 7 - 1 9 6 5}$ & Period of relatively successful development of co-operatives \\
\hline $\mathbf{1 9 7 4}$ & The SFRY Constitution \\
\hline $\mathbf{1 9 7 6}$ & The Law on Associated Labor has been adopted, with which the cooperatives are \\
\hline $\mathbf{1 9 8 9}$ & Return to co-operatives and reinstatement of cooperative property by the 1988 \\
\hline $\mathbf{1 9 9 0}$ & Constitution \\
\hline $\mathbf{1 9 9 6}$ & The new Law on Cooperatives has been adopted \\
\hline $\mathbf{2 0 1 5}$ & The law on cooperatives adopted \\
\hline
\end{tabular}

Source: Tomić, 2017.

The agricultural cooperative, as a model of interest-based association of farmers, is not an end in itself, but a means of achieving the goals of its members-associates who are "working together" in order to achieve better results working on family farms.

According to The National Agriculture and Rural Development Strategy of the Republic of Serbia, adopted in 2012, on the initiative of the Society of Agricultural Economists of Serbia, the cooperative acts as a generator of economic development of agriculture in several directions:

1. pretends to become the main entrepreneurial form through which Serbian farmers will constantly improve their economic situation;

2. in cooperation with the cooperative, the easiest way for farmers to transfer traditional agriculture to modern ones is by purchasing inputs through a cooperative at the most favorable prices and receive expert instructions on how to use them;

3. gathering small farmers of cooperatives as an economic service for cooperatives, through marketing information, directs cooperatives to a production structure that delivers optimal results, helping them find where and when to sell their products at the best price; 
4. working with the cooperative according to the "model of contracted production", a higher employment of household members in family farms is achieved, resulting in their economic strengthening through the realization of higher incomes;

5. in the market conditions, the cooperative must verify its competitiveness, and by performing its economic functions in the name and for the account of the cooperative, it strengthens the market position of family farms, which provides them with more efficient business;

6. the cooperative contributes to the stabilization of economic trends and the reduction of the gray economy, resulting in higher tax revenues, the reduction of illegal business and the reduction of unfair competition;

7. by forming cooperative enterprises in the manufacturing industry, cooperatives enable their members to become owners of a recognizable cooperative product of greater added value;

8. the cooperative reduces the economic stratification of the population in the transition process in a more just way because cooperative farmers can help one another (http://portal.zzbaco.com/mojo_baco/Data/Sites/1/daes_brosura_ strategija.pdf).

However, this Strategy has never been adopted by the National Assembly as a strategic document, but based on the allegations in it, the reform of the co-operative society in Serbia was adopted and a new Law on Cooperatives in 2015 ("Official Gazette of the Republic of Serbia" No. 112/2015) was adopted, in which the basic concepts related to cooperatives are defined, the basic principles of cooperatives are determined and the legal position of the cooperatives on the market is determined. The law stipulates that the cooperative is a legal entity, as a special form of association of natural persons, which is a special form of organization of physical persons (hereinafter referred to as "a cooperative member") that realizes its economic, social, cultural and other interests by operating on cooperative principles, and that manages and controls the operations of the cooperative.

(Article 2 of the Law on Cooperatives). From the very definition of the term cooperative law, several conclusions can be drawn. First of all, a cooperative is designated as a legal entity, which acquires its subjectivity by registering it in the prescribed register (the Business Registers Agency). Therefore, by registering in the prescribed register cooperatives can on its own perform on the market in its own name and for its own account, independently of the cooperative - the individual who established it. This definition of a cooperative is very important because the same rules apply on other legal entities (Bulatović et al., 2016), and the individual will and interests of the cooperative founder must be transformed into a general or joint interest, through a cooperative as a legal entity. 
Bearing in mind that there are about 1600 active agricultural cooperatives in Serbia, and that there are 30-40 cooperatives on average, there can be conflicts of interest that exist in other legal forms of companies (limited liability company and joint-stock company). (http://pretraga2.apr.gov.rs/ObjedinjenePretrage/Search/Search). These conflicts primarily arise from the conflicts of individual and common interests, ie of general interests (Škorić, 2010). The specificity of conflicts of different interests of a cooperative arises from the basic principles of cooperative society, which co-operatives put in a special group of economic organization.

The Law on Cooperatives regulates the way of organizing cooperatives, i.e. management of a cooperative, cooperative bodies, decision making, etc. (Article 33-52 of the Law on Cooperatives). Co-operatives manage a cooperative on the principle of "one cooperative - one vote" in the assembly of the cooperatives, while the cooperative bodies are: the assembly, the board of directors, the supervisory board and the director. The issues regarding the responsibility of the members of the cooperative bodies, which are not resolved by this law, are subject to the provisions of the Law on Business Companies, which concern special duties towards the company ("Official Gazette of the Republic of Serbia" No. 36/2011, 99/2011, 83/2014 - Dr. Law and 5/2015). In this regard, one could imagine situations in which the determination of the responsibility of the cooperatives would be necessary, as well as the review of the decisions made by the shareholders assembly, etc. (Mirković \& Maričić, 2017).

On the basis of all the above, the challenges and problems of the agricultural cooperatives in Serbia so far, and on the basis of the beginning of the reform of the cooperative sector, conditioned by the problems identified that require urgent resolution, one can find a place for applying the principles of corporate governance as a way of making business decisions in cooperatives, which would contribute to the further and faster development of the agricultural cooperatives in Serbia.

\section{Discussions}

Corporate governance, as a way of thinking, appeared almost a century before the term officially began to be used, so the idea of corporate governance is actually older, but in theory and practice it is stated as new. He even has the opinion that corporate governance was created at the same time as the forms of organization in which there is a conflict between those who invest money and capital and those who manage it (Jovanović \& Grujić, 2016).

Corporate governance is a set of clearly defined rules and processes that regulate the system of relationships between different stakeholders in the company and beyond, all with the aim of implementing strategic decisions, ensuring long-term growth and development of companies and increasing the wealth of shareholders (Vučković \& Vučković, 2016). The development of the concept of corporate governance is based on a number of theories, of which the most dominant "agency theory," which separates the ownership and management functions of the company analytically, and this refers 
to the complex relationship between shareholders and managers, which results in the emergence of information asymmetry (Jensen \& Meckling, 1976).

Corporate governance involves a set of mechanisms that by adjusting and aligning contribute to the introduction and improvement of the rule of law for the company. Developed countries were in the 60 s and 70 s (when privatization came to their notice) showed great interest in synthesizing and solving corporate governance issues. The success of the privatization was conditioned by the state-of-the-art model of good corporate governance provided through the legal and institutional framework of the state with the aim of serving the developed countries in fighting corruption from the point of view of companies (that is, microeconomic entities) and for strengthening the economy as a whole from a macroeconomic point of view (through strengthening and expanding companies outside the framework of the domestic economy) (Đorđević, 2004, p. 196). Their goal is to establish a corporate governance practice that ensures the protection of shareholders and investors against misuse of the board. Different economic trends in market economies have led to the emergence of several types of capitalism(Josifidis, 2: 2004):

1. Market-oriented capitalism characteristic for the US, UK and Canada,

2. Rhineland or corporative capitalism characteristic for Germany and Japan,

3. State capitalism recognizable in France and Italy and

4. Social democratic capitalism characteristic of Sweden and Austria

Crystallized types of capitalism, together with the administrative and legal environment, the cultural and historical development of countries and the increasingly developed market economy, led to the differentiation of three systems of corporate governance:

1. One-tier system of corporate governance (one-tier system) developed in Anglo-Saxon countries (USA, UK, Canada) - characterized by one body governing society, including both executive and non-executive members. In such an environment, the Supervisory Board is often referred to as the Steering Committee, and it is very important that the position of General Director and the Chairman of the Board of Directors is taken by the same person. This system facilitates the creation of strong management structures and effective decision making. However, non-executive and independent directors play a crucial role in monitoring leadership and reducing executive costs.

2. A two-tier system of of corporate governance, characteristic for Germany and Japan - characterized by the existence of a separated Supervisory Board (supervisory board) and aBoard of Directors (executive board). Under this system, day-to-day management of the company has been handed over to the executive committee controlled by the Supervisory Board elected by the Assembly. These two bodies have separate powers and their composition can not be combined. The advantage of such a system is a clear control mechanism, but ineffective decision making is undermined. 
3. A mixed system of corporate governance, widely accepted in transition countries, featuring the characteristics of the two above mentioned management models (Kaster, 1992).

At the beginning of the 21 st century, corporate governance was even more important due to the increase in the number of scandals and crises that occurred in those years. Crises in large companies such as Enron, WorldCom, Tyco and others have led to a number of reassessments of the role of independent directors, committees, etc. and it led to a review of the professional ethics of companies (Jovanović \& Grujić, 2016). Numerous crises have led to the strengthening of the role of corporate governance and increasing its importance in economic development. The causes of problems in the 21 st century, such as privatization, technological development, liberalization and the opening up of financial markets, trade freedom and other structural reforms, have enhanced the role of corporate governance, but at the same time it has complicated its functioning and application, with greater investor rights, growth international financial integration, trade and investment, and more difficult corporate governance outside the state borders (Claessens, 2003). The financial crisis 2007-2008 resulted in the discovery of the weaknesses of corporate governance that did not pass the crisis momentum test and where the previous management routine turned out to be very weak - many companies did not manage to protect themselves from various financial risks, etc. Subsequently, the importance of effective supervision of the board of directors and managerial decision-making and management of the company became apparent (Kirkpatrik, 2009).

Therefore, it is precisely during the crisis years that all the principles of corporate governance have been tested, as well as its ability to adapt to the new circumstances on the market. Hence the need to modify the principles of corporate governance and upgrading as a way of managing the company, both by the way and the process of reaching every decision that pretends to be the decision of the majority in the company and control over given decision-making processes and management of the company.

Today's modern agriculture and agribusiness consistently puts ever more stringent demands for decision-making at all levels, whether it is national agriculture or a family farm (Nedeljković et al., 2017). If the specificities characteristic of the agricultural cooperatives are added to this, then this process of deciding how to manage and manage the cooperative is far more complicated.

Some authors group factors that distinguish business decision-making in agribusiness from other branches of the economy, in the following way (Srđević, 2006):

1. International factors (international and neighborly general political relations, customs, contingents, subsidies).

2. Domestic state factors (organization and competence, development strategy, legislation, financing, loans).

3. Fees and prices (price policy, regulations, contracts, controls, collection, budgeting). 
4. Ownership of agricultural and related resources (state, private, mixed).

5. Loans (long-term, short-term, interest rates).

6. Investments (capital, loans, investors).

7. New technologies (transport, storage, systems, equipment, materials, IT resources and infrastructure).

8. Factors related to heritage and experience.

9. Perception of existing and anticipation of possible risks of agricultural production.

10. Willingness to adopt new knowledge and technology.

11. Willingness (motivation) to participate in decision-making and participates in the responsibility of the implementation of decisions.

Therefore, in order to achieve success in the agribusiness, proper and adequate managerial decisions must be made about the development of production, its structure and investments, etc. (Vujatović \& Stojanović, 2008).

In what way, on the basis of everything mentioned above, apply the principles of corporate governance in agricultural cooperatives. If corporate governance is defined as a set of rules for the proper management of a company, then the protection of the rights of minority shareholders that are not equal in decision-making etc., then we must apply different corporate governance so differently to cooperatives. Namely, in agricultural cooperatives one of the basic principles of management is the rule "one cooperative one vote", and in the assembly of the cooperative all have the same right to decide. The Law on Cooperatives (Article 13) lists the application of the provisions of the Law on Companies that regulate the legal position of the limited liability company, on all issues not regulated by the Law on Cooperatives.

Therefore, in this sense, the Cooperative is considered as a company and, as such, with all its specifics, has its own bodies, the assembly, the administrative and the supervisory board and the director, and all the rules of corporate governance and decision making can be applied to business decision making, operation and management the agricultural cooperative, taking into account the motive of its establishment, characteristics of membership, basic values, support and protection enjoyed by the state.

Thus, the chance of survival on the market in extremely turbulent times, where profit is above all possible values, and the richness of investors above the basic and perhaps even moral values of man are increasing.

In accordance with the positive legal regulations of agricultural cooperatives, what model of corporate governance could be applied in the management of the agricultural cooperatives? Although according to the provisions of the Law, the cooperative is managed by the cooperatives, however, the director who represents the cooperative, organizes and manages business, ensures legality and is responsible for the lawful 
operation of the cooperative, prepares prepare a working plan and development program and other (Article 48 of the Law on Cooperatives). Also, it is stipulated that the director of a cooperative does not have to be a member of a cooperative, that is, that he can be an independent member, along with, of course, provisions regarding the prohibition of competition (performing the same or similar jobs in another cooperative of the same or similar activity, as well as membership in another cooperative, etc.). Analyzing the Law, it has been established that the management of the cooperative has implemented a bicameral management system, where the Supervisory Board controls the work of the director of the cooperative. Although the same law provides for the appropriate implementation of the Law on Companies, the part concerning the limited liability company, for the management of the cooperative, as stated, the model of the bicameral management system is used, while for a limited liability company in the Companies Act, the possibility of choosing between the one-tonne (where the work of the director is supervised by the assembly) and the bicameral management system (Maričić, 2016). Therefore, in the Law on Cooperatives the legislator prescribed double control in the management of the cooperative, that is, that the work of the director is controlled by the first board of directors and then by the supervisory board, and that the administrative and supervisory board, on the other hand, elects the assembly of the cooperative, which can not be simultaneously members of both organs. In addition to the work of the director, the supervisory board controls the work of the management board, and the control of the management takes place on several levels. So even though the director of a cooperative can be a person who is not a cooperative, his work is controlled by the first board of directors, and the supervisory board and at the end of the assembly of the cooperative, who ultimately chooses and dismisses the duties of the director of the cooperative. From this structure of the management of the agricultural cooperative, a better business decision can be expected, which is more controlled by the cooperatives and, as such, can fully apply the principles of corporate governance, although it is practically not a big legal and economic system. However, if the condition for the establishment of an agricultural cooperative is at least 5 business-minded individuals, how can the system of multiple control be applied? It would not be practically unhelpful, due to the insufficient number of co-workers who would be members of the management and supervisory boards, and theoretically would be unnecessary, due to the hypothetical lack of pluralism of interest, since then the association is simpler and also management is in the interest of all.

\section{Conclusion}

Although global and domestic literature linkes corporate governance to large-scale economic systems, its rules can easily be adapted to smaller companies, and to specific legal entities, such as agriculture cooperatives. Only here, instead of the corporate governance code, cooperative values are applied and principles established by law, and corporate governance modify and adapt with their specific objectives. For agricultural cooperatives, which have more cooperatives, it is even necessary to apply proper management for the survival of cooperatives, increasing their competitiveness on the 
market of agricultural products, and even the survival of the Serbian village that gets "old and extincts". The state's obligation is to enable the recovery and sustainable development of the Serbian village, and thus the overall development of rural areas, through the stimulation of agricultural cooperatives, or the association of small agricultural holdings. Also, the fact that the Strategy for the Development of Agricultural Cooperatives has not been officially adopted, and that in the Strategy of Agriculture and Rural Development, only few pages are given to cooperatives, it supports the fact that there has not yet been enough effort to popularize agricultural cooperatives, that the future cooperatives and others who still do not know that this is how they would more easily protect and realize their interests in agricultural production, educated on what are the basic values of cooperatives. The basic path towards reform and encouraging the development of the given area, certainly begins with legislative and institutional frameworks, but education is the one that will bring closer the basic ideas, the meaning and the values of the agricultural cooperatives to all interested persons. Only after that, it is possible to expect the practical revival of co-operatives and associations in general on cooperative bases, which are as such established more than 100 years ago.

\section{Conflict of interests}

The authors declare no conflict of interest.

\section{References}

1. The Serbian Business Registers Agency (APR), Retrieved from http://pretraga2. apr.gov.rs/ObjedinjenePretrage/Search/Search (March 15, 2018)

2. Bulatović, I., Škorić, S., Jovanović, V. (2016) Branding the business name. Economics of agriculture, 63(4): 1323-1332, DOI: 10.5937/ekoPolj1604323B

3. Claessens, S. (2003) Corporate Governance and Development. A Global Corporate Governance Forum, Focus 1, The International Bank for Reconstruction and Development, Washington.

4. Đorđević, M. (2004) Corporate governance: genesis, models, problems. Privredna izgradnja 47(3-4): 191-212, DOI: 10.2298/PRIZ0404191D [in Serbian: Đorđević, M. (2004), Korporativno upravljanje - geneza, modeli i problemi].

5. Jensen, M. \& Meckling, W. (1976) Theory of the Firm: Managerial Behavior, Costs and Ownership Structure. Journal of Financial Economics, Harvard University Press 3(4): 305-360, DOI: 10.1016/0304-405X(76)90026-X

6. Josifidis, K. (2004) Modern Capitalism: Multiformity vs. Uniformity, Prizma 1(2): 52-67. [in Serbian: Josifidis, K. (2004), Moderni kapitalizam: multiformnost vs uniformnost].

7. Josifidis, K. (2004): Macroeconomics: principles, theories, politics. Vedes, Beograd. [in Serbian: Josifidis, K. (2004) Makroekonomija: principi, teorije, politika]. 
8. Jovanović, J. \& Grujić, B. (2016) Historical development of corporate governance as the basis for current corporate trends. Ekonomika, 62(1): 187198, DOI: 10.5937/ekonomika1601187J. [in Serbian: Jovanović, J. \& Grujić, B. (2016) Istorijski razvoj korporativnog upravljanja kao osnova za aktuelne korporativne trendove].

9. Kester, C. (1992). Governance, Contracting, and Investments Horizons: Look at Japan and Germany. Journal for Applied Corporate Finance, 5(2): 83-98.

10. Kirkpatrick, G. (2009) The Corporate Governance Lessons from the Financial Crisis, OECD, Pre-publication version for Vol. 2009/1, Retrieved from https:// www.oecd.org/finance/financial-markets/42229620.pdf (March 16, 2018)

11. Maričić, G. (2016) Bodies of management of a limited liability company in the Republic of Serbia and the Republic of Srpska. Pravo, teorija i praksa, 33(4-6): 48-60. [in Serbian: Maričić, G. (2016) Organi upravljanja društva sa ograničenom odgovornošću u Republici Srbiji i Republici Srpskoj].

12. Mirković, P., Maričić, G. (2017) Adoption of decisions of the assembly of the joint-stock company. Kultura Polisa, 14(34): 331-342. [in Serbian: Mirković, P., Maričić, G. (2017) Pobijanje odluka skupštine akcionarskog društva].

13. Nedeljković, M., Zoranović, T, Vukoje, V. i Plavšić, M. (2017) Business decision making in agriculture and agribusiness. Agroekonomika, No. 76: 5565. [in Serbian: Nedeljković, M., Zoranović, T, Vukoje, V. i Plavšić, M. (2017) Poslovno odlučivanje u poljoprivredi i agrobiznisu].

14. Srđević, B. (2006) Multicriteria and social decision-making methods in modern agriculture. Savremena poljoprivredna, No. 55: 1-8. [in Serbian: Srđević, B. (2006) Višekriterijumski i društveni metodi odlučivanja u savremenoj poljoprivredi].

15. The Strategy of Agriculture and Rural Development of the Republic of Serbia for the period of 2014-2014, „Official Gazette of RS“ No. 85/14

16. Strategy for the development of agricultural cooperatives in the Republic of Serbia (2012), Ministry of Agriculture, Forestry and Water Economy, Društvo agrarnih ekonomista Srbije, Beograd. [in Serbian: Strategija razvoja zemljoradničkog zadrugarstva u Republici Srbiji (2012), Ministarstvo poljoprivrede, trgovine, šumarstva i vodoprivrede]. Retrieved from http://portal. zzbaco.com/mojo_baco/Data/Sites/1/daes_brosura_strategija.pdf(March 15, 2018)

17. Škorić, S. (2010) Law, economy and pluralism of interest. Pravo i politika No. 2: 171-181. [in Serbian: Škorić, S. (2010) Pravo, privreda i pluralizam interesa].

18. Tomić, D, Gulan, B., Kostov, R. (2017) Guide through the Cooperative of Serbia. Praktični priručnik, Beograd. [in Serbian: Tomić, D, Gulan, B., Kostov, R. (2017) Vodič kroz zadrugarstvo Srbije].

19. Law on Cooperatives, „Official Gazzete of RS““ No. 112/2015 
20. Law on Companies, „Official Gazette of RS“ Nos. 36/2011, 99/2011, 83/2014 and $5 / 2015$

21. Vignjević - Đorđević, N., Jovićević, P., Kocić, S (2015) Specifics of corporate managment in agribusines in transitional conditions. Economics of agriculture, 62(3): 869-879.

22. Vučković, V. \& Vučković, S. (2016) Development of Corporate Governance in Transition Countries of Europe. Megatrend revija 13(2): 37-58. [in Serbian: Vučković, V. i Vučković, S. (2016) Razvoj korporativnog upravljanja u tranzicionimzemljama Evrope].

23. Vujatović, Z. \& Stojanović, Ž. (2008) Economics of agrar, Ekonomski fakultet, Beograd. [in Serbian: Vujatović, Z. \& Stojanović, Ž. (2008) Ekonomika agrara].

24. Vukoje, V. \& Zekić, V. (2010) Economic position of agricultural enterprises in Vojvodina (2001-2009). Economics of agriculture, 57(3): 425-435.

25. Cooperative Union of Serbia [in Serbian: Zadružni Savez Srbije]. Retrieved from http://www.zssrbije.org/istorija-zadrugarstva.html (March 15, 2018) 